\title{
腹膜透過能の新しい簡易評価式の導出
}

\author{
山下 明泰＼cjkstart濱田 浩 幸 \\ 九州工業大学情報工学部生物化学システム工学科
}

key words : 腹膜透析, 総括物質移動・膜面積係数, 反撥係数, 古典的式, キネティック式

〈要旨〉

古典的な膜透過理論に基づく腹膜透過モデルには様々なものがあるが，本論文では小分子溶質について，PylePopovich の厳密な理論に忠実な新しい簡易モデル（以下，本簡易式）を導出した. Pyle-Popovich のモデルをもと に生成した仮想の臨床データに対して, 対流輸送を考慮していない Henderson の式, 単一方向への対流輸送のみ考 慮した Babb-Garred の式，および本簡易式を当てはめる計算機実験を行い，総括物質移動·膜面積係数 (MTAC) を算出した. PET (peritoneal equilibrium test) データをもとに 4 時間目の検査值を用いれば，いずれの簡易式を 用いても比較的小さな誤差で MTAC を求めることができた。 しかし除水不良例や除水過剩例において, 特に短時間 の検査データを用いると, 前 2 つの簡易式では MTAC の算出値には大きな誤差 (Henderson の式では over-estimation, Babb-Garred の式では under-estimation)を生じる可能性が明らかとなった。このような場合にも, 本簡易式 を用いれば士5.0\%以内の誤差で MTAC を求められることがわかった. また, Henderson や Babb-Garred の式から 求めた MTAC の值は, 採取する臨床データの時間に大きく影響を受けるのに対し, 本簡易式によるMTAC の計算結 果は，臨床データの採取時間に影響を受けにくいことがわかった。

これまでに採取されたPET による検査データを生かし, 腹膜透過能を定量的に把握するために, 本簡易式は有用 と思われた.

\section{New simple mathematical model for evaluation of peritoneal permeability}

Akihiro C. Yamashita, Hiroyuki Hamada

Department of Biochemical Engineering and Science, College of Computer Science and Systems Engineering, Kyushu Institute of Technology at Iizuka

The authors derived a novel simple peritoneal transport equation for small solutes based on the most rigorous Pyle-Popovich's model. Computational curve-fittings were calculated for data generated by the PylePopovich's model using three simple kinetic equations, i. e., Henderson's (no convection), Babb-Garred's (convection from blood to dialysate only), and a new model that includes more precise effects of convection, to determine which of these three models returned most accurate MTAC (overall Mass Transfer-Area Coefficient) value. The mathematical forms of these three equations are remarkably similar, although the basic concept or assumptions for derivation are totally different. Slight discrepancies were found between these three models when $4 \mathrm{hr}$-concentration data were used. Considerable errors, however, appeared with the former two models for data obtained in the case of "UF failure" or "Excess UF", especially when a shorter time (less than $2 \mathrm{hrs)} \mathrm{for} \mathrm{data} \mathrm{collection} \mathrm{was} \mathrm{used.} \mathrm{Even} \mathrm{under} \mathrm{such} \mathrm{circumstances,} \mathrm{the} \mathrm{new} \mathrm{simple} \mathrm{model} \mathrm{calculated} \mathrm{accurate}$ MTAC values with a small error rate $( \pm 5.0 \%)$. Since analyzing patients' peritoneal function is becoming more important these days, the new kinetic model that requires only PET (peritoneal equilibrium test) data may be a useful tool for calculating MTAC values.

山下 明泰 九州工業大学情報工学部生物化学システム工学科

テ 820-8502 飯塚市大字川津 680-4 (0948-29-7836)

Akihiro Yamashita Fax 0948-29-7801 


\section{緒言}

腹膜透析における最大の問題点は腹膜炎の発症とい われている，最近では硬化性被囊性腹膜炎が新たな問 題点となりつつあり, CAPD をいつまで続けるか, い つ中止するかについて, 栄養学的な指標 ${ }^{1)}$ や種々の腹 膜機能の検査法が提案されている. 古典的な物質移動 モデルに基づく代表的な腹膜機能の検査法は，腹膜平 衡試験 (peritoneal equilibrium test；PET) 2)である が，これは透過性の元進状態を 4 段階に分類する定性 的な評価法である。これを定量的に表現するには数式 の運用が必要であるが, その数式にも複雑で精度が高 いものから，多少の精度を犠牲にした簡便なものまで いろいろなモデルが知られている。本論文では, 簡便 でかつ精度の高い評価ができる新たな簡易式を導出 し，既報のモデルと比較した。

\section{I. 理 論}

腹膜透析における物質移動現象を，体液および腹腔 内透析液をそれぞれ, 完全混合槽とみなした2-コン パートメントモデルで解析すると, その物質収支は体 液槽, 透析液槽の各々について,

$$
\begin{aligned}
& \frac{d\left(V_{B} C_{B}\right)}{d t}=G-\dot{m} \\
& \frac{d\left(V_{D} C_{D}\right)}{d t}=\dot{m}
\end{aligned}
$$

と書くことができる。ここで，Cは着目溶質の濃度 $[\mathrm{mg} / \mathrm{ml}], G$ は着目溶質の生成速度 $[\mathrm{mg} / \mathrm{min}], \quad V$ は 各コンパートメントの容積 $[\mathrm{m} l], t$ は透析液の貯留時 間 $[\mathrm{min}], \dot{m}$ は物質移動速度 $[\mathrm{mg} / \mathrm{min}]$, 添字 $B$ は体 液 (または血液)，Dは透析液を表す。（1- a )，(1-b ) 式中の $\dot{m}$ にどの形式を採用するかで，モデルの基本 的な概念が決まる。

\section{Pyle-Popovich のモデル}

Pyle と Popovich³ は, $\dot{m}$ を

$$
\begin{aligned}
& \dot{m}=K A\left(C_{B}-C_{D}\right)+(1-\sigma) Q_{u} \bar{C} \\
& \bar{C}=C_{B}-f\left(C_{B}-C_{D}\right) \\
& f=\frac{1}{\beta}-\frac{1}{\exp (\beta)-1} \\
& \beta=\frac{Q_{u}(1-\sigma)}{K A} \\
& Q_{u}=a_{1} \exp \left(a_{2} t\right)+a_{3}
\end{aligned}
$$

と, 均質膜の透過理論としては最も正確な形で表示し た。ただしここに，Aは腹膜の有効面積 $\left[\mathrm{cm}^{2}\right], K$ は
総括物質移動係数 $[\mathrm{cm} / \mathrm{min}], \bar{C}$ は（3）式で定義され る腹膜内平均濃度 $[\mathrm{mg} / \mathrm{ml}], f$ は (4) 式で定義され る重み因子 $[-], Q_{u}$ は正味の限外濾過速度 $[\mathrm{m} l /$ $\min ], \beta$ はペクレ数 $[-], \sigma$ は Staverman の反撥係 数 $[-], a_{1}[\mathrm{ml} / \mathrm{min}], a_{2}[l / \mathrm{min}], a_{3}[\mathrm{~m} l / \mathrm{min}]$ は $Q_{u}$ を決定する実験的定数である。また $K$ と $A$ との 積 $K A[\mathrm{~m} l / \mathrm{min}]$ は通常, 腹膜の総括物質移動・膜面 積係数 (overall mass transfer-area coefficient; $M T A C)$ と呼ばれ，この值を算出することで腹膜透過 能を定量的に把握することができる。また，(1) 式中 の体液および透析液の容積については次式を用いる。

$$
\begin{aligned}
& V_{D}-V_{D}(0)=\frac{a_{1}}{a_{2}}\left\{\exp \left(a_{2} t\right)-1\right\}+a_{3} t \\
& V_{B}+V_{D}=V_{B}(0)+V_{D}(0)
\end{aligned}
$$

このモデルは現象を記述するには優れているが，モデ ルの運用には多点のデータ採取に加え, コンピュータ を用いた数值計算が必要であり, 臨床的な実用性はあ まり高くない.

\section{Henderson のモデル}

物質の移動が分子拡散に支配される小分子物質の場 合，腹膜を介した濾過による物質移動の効果は大きく ない.さらに Henderson は, 腹膜透析では体 (血) 液 中の溶質濃度がほぼ不変であることから，これを平均 值 $\bar{C}_{B}$ （一定）で代表させて,

$$
\dot{m}=K A\left(\bar{C}_{B}-C_{D}\right)
$$

と書いた ${ }^{4)}$. Henderson は透析液量の変化を無視した が，本研究では平均值 $\bar{V}_{D}$ (一定) を用いる形に修正し， (2-b) 式を (1-a) 式と組み合わせると，

$$
\frac{C_{D}-\bar{C}_{B}}{C_{D}(0)-\bar{C}_{B}}=\exp \left(-\frac{K A}{\bar{V}_{D}} t\right)
$$

が得られる。

\section{Babb-Garred のモデル}

Babb $^{5)}$ そして後に Garred ${ }^{6)}$ は Hendersonの式を 改良する形で, $(2-\mathrm{b})$ 式に篩のかからない（ $\sigma=0.0)$ 濾過の効果を加味して,

$$
\dot{m}=K A\left(\bar{C}_{B}-C_{D}\right)+Q_{2} \bar{C}_{B}
$$

と書いた。 これと（1-b) 式とを組み合わせると，

$$
\frac{C_{D}-\bar{C}_{B}}{C_{D}(0)-\bar{C}_{B}}=\frac{V_{D}(0)}{V_{D}} \exp \left(-\frac{K A}{\bar{V}_{D}} t\right)
$$

となる。

\section{4. 新しいモデル}

Pyle-Popovich のモデルにおいて，篩のかからない 濾過の効果を加味するためには， $\sigma=0.0$ とおけばよ い.すなわち, 
表 1 Input data for ultrafiltration curves

\begin{tabular}{|c|c|c|c|c|c|}
\hline \multirow[b]{2}{*}{$\#$} & \multirow[b]{2}{*}{ Ultrafiltration curves } & \multicolumn{3}{|c|}{ Ultrafiltration parameters } & \multirow{2}{*}{$\begin{array}{c}\text { Initial dialysate volume } \\
\qquad V_{D}(0) \\
{[\mathrm{m} l]}\end{array}$} \\
\hline & & $\begin{array}{c}a_{1} \\
{[\mathrm{~m} l / \mathrm{min}]}\end{array}$ & $\begin{array}{c}a_{2} \\
{[1 / \mathrm{min}]}\end{array}$ & $\begin{array}{c}a_{3} \\
{[\mathrm{~m} l / \mathrm{min}]}\end{array}$ & \\
\hline 1 & Normal UF & 8.07 & -0.021 & -0.671 & 2,000 \\
\hline 2 & UF failure & 17.20 & -0.050 & -0.050 & 2,000 \\
\hline 3 & Excess UF & 4.00 & -0.008 & -0.008 & 2,000 \\
\hline 4 & Low hydraulic permeability & 1.00 & -0.005 & -0.005 & 2,000 \\
\hline
\end{tabular}

表 2 Set parameters for generating simulation data by Pyle-Popovich's model

\begin{tabular}{|c|c|c|c|c|c|c|}
\hline \multirow{2}{*}{ Solutes } & \multicolumn{2}{|c|}{ Initial concentrations $[\mathrm{mg} / \mathrm{m} l]$} & \multirow{2}{*}{$\begin{array}{c}\text { Generation rate } \\
{[\mathrm{mg} / \mathrm{min}]}\end{array}$} & \multirow{2}{*}{$\begin{array}{l}\text { Initial body fluid } \\
V_{D}(0)[\mathrm{m} l]\end{array}$} & \multirow{2}{*}{$\begin{array}{c}M T A C \\
{[\mathrm{ml} / \mathrm{min}]}\end{array}$} & \multirow{2}{*}{$\begin{array}{c}\sigma \\
{[-]}\end{array}$} \\
\hline & Blood & Dialysate & & & & \\
\hline Urea & 0.800 & 0.0 & 5.700 & 36,000 & $20.0^{8)}$ & $0.212^{8)}$ \\
\hline Creatinine & 0.104 & 0.0 & 0.506 & 36,000 & $13.0^{8)}$ & $0.255^{8)}$ \\
\hline
\end{tabular}

MTAC $\cdots$ overall mass transfer-area coefficient $\sigma \cdots$ Staverman's reflection coefficient

$$
\dot{m}=K A\left(C_{B}-C_{D}\right)+Q_{u} \bar{C}
$$

となる。形を決定するために（3）式を用いるが, これは (4) 式中の $f$ の值を定めることに帰着する。と ころが本研究で検討した 4 つの除水曲線を含め，考慮 しうる総ての場合において, $f$ は $0.40<f<0.55$ の範 囲の值しかとらない(摘要第 1 項参照).そこで, $f \approx$ $0.5=1 / 2$ と近似しても実用上問題はない。このとき (3) 式は

$$
\bar{C} \approx C_{B}-\left(\frac{1}{2}\right)\left(C_{B}-C_{D}\right)=\frac{C_{B}+C_{D}}{2}
$$

となる。ここで Henderson や Babb-Garred のモデル 同様, 血中濃度を平均値 $\bar{C}_{B}$ (一定) で代表させれば, (2-d) 式は

$$
\dot{m}=K A\left(\bar{C}_{B}-C_{D}\right)+Q_{u}\left(\frac{\bar{C}_{B}+C_{D}}{2}\right)
$$

となる。これを（1-b) 式に代入して，解くと (導出の詳細は摘要第 2 項参照)

$$
\frac{C_{D}-\bar{C}_{B}}{C_{D}(0)-\bar{C}_{B}}=\left\{\frac{V_{D}(0)}{V_{D}}\right\}^{(1 / 2)} \exp \left(-\frac{K A}{\bar{V}_{D}} t\right)
$$

を得る。

\section{II. 計算機実験の方法}

まず，最も良好に臨床データを再現することができ る Pyle-Popovich のモデルに $K A$ および $\sigma$ の值を与 えて，仮想の臨床データを生成した。こうして得られ たデー夕に（9）（10）および（13）式を適用して $K A$ の值を求め, どの方法で求めた $K A$ が元の值に最も近 いかを検討した。これらの簡易式を変形すると,

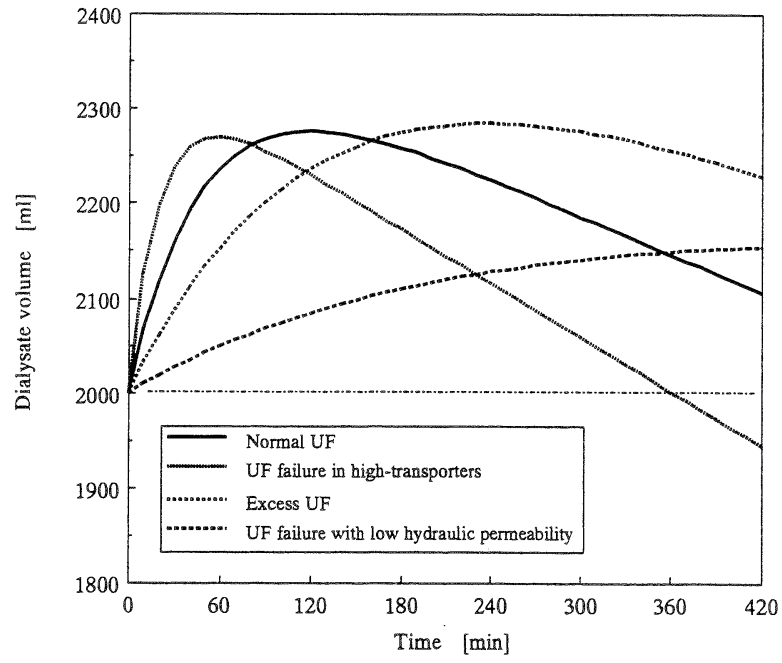

図 1 Various patterns of dialysate volume change chosen for computer simulations

$$
\ln \left[\left(\frac{V_{D}}{V_{D}(0)}\right)^{n}\left(\frac{C_{D}-\bar{C}_{B}}{C_{D}(0)-\bar{C}_{B}}\right)\right]=-\frac{K A}{\bar{V}_{D}} t
$$

とまとめることができる（ $n=0,1 / 2,1)$ 。すなわち横 軸に時間 $t$, 縦軸に $-\ln \left[\left(V_{D} / V_{D}(0)\right)^{n}\left(\bar{C}_{B}-C_{D}\right) /\right.$ $\left.\left(\bar{C}_{B}-C_{D}(0)\right)\right]$ を取れば，実験（臨床）データは原点 を通る右上がりの直線上に並ぶ。この直線の勾配が $K A / \bar{V}_{D}$ であるから， $\bar{V}_{D}$ を乗じて $K A$ を算出した。 この $\bar{V}_{D}$ の算出には種々の方法が提案されている77が, 本論文の計算機実験では，以下の積分平均値を用いた (導出は摘要第 3 項参照). すなわち,

$$
\bar{V}_{D}=\left(V_{D}(0)-\frac{a_{1}}{a_{2}}\right)+\frac{a_{3}}{2} t+\frac{a_{1}}{a_{2}{ }^{2} t}\left\{\exp \left(a_{2} t\right)-1\right\}
$$

である。 

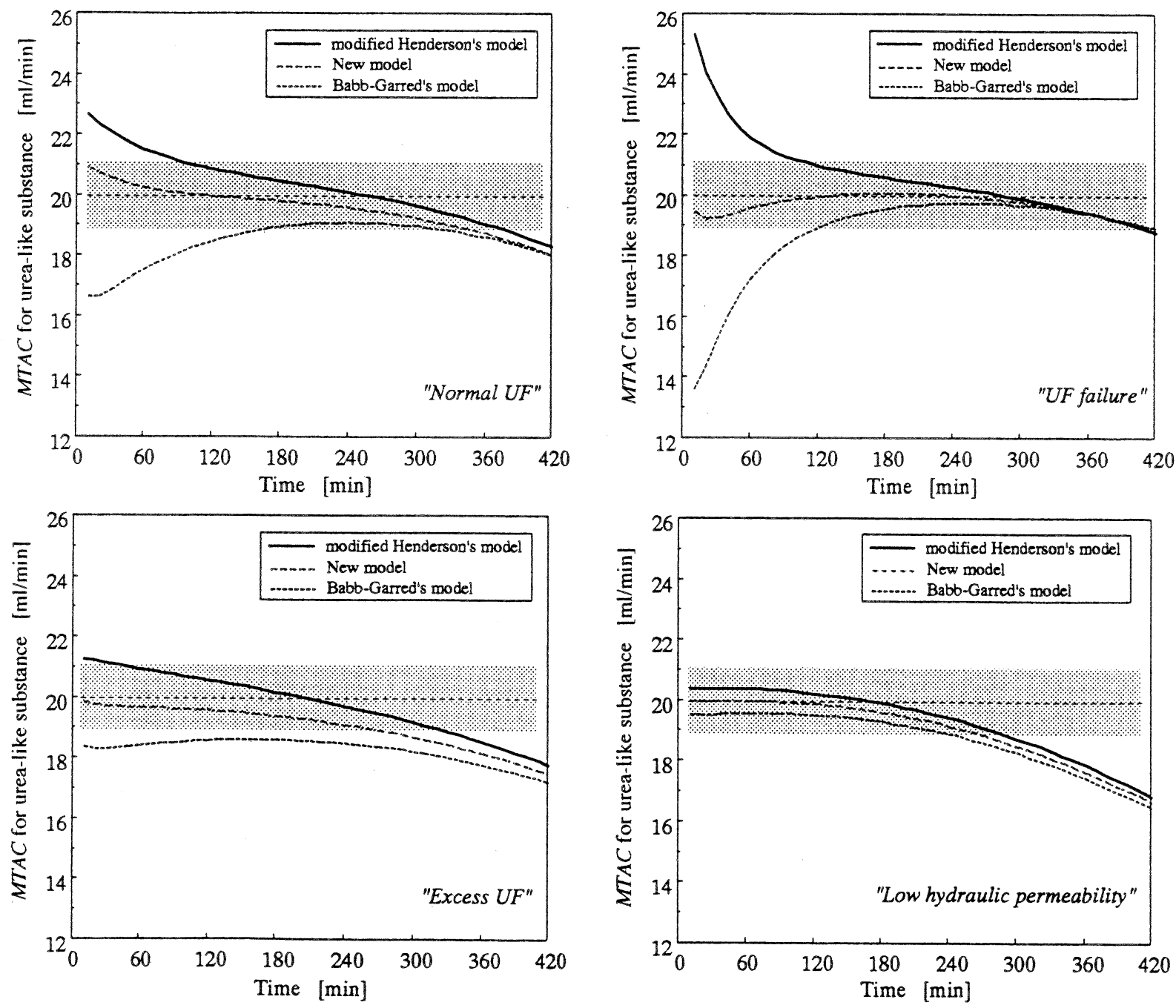

図 2 Comparison of three simple kinetic models in calculation of MTAC for urea-like substance Top-Left : "Normal UF" Top-Right: "UF failure"

Bottom-Left : "Excess UF" Bottom-Right : "Low hydraulic permeability"

除水曲線は図 1 に示した 4 つのパターンとした。I 型は除水正常（良好）例でこの場合の除水パラメー夕 $\left(a_{1}, a_{2}, a_{3}\right)$ には著者らが報告した值 ${ }^{8)}$ (表 1 ）を用い た。 II型は腹膜炎を含む透過克進時に見られる除水不 良例, III型は除水過利例, IV型は腹膜の透水能が低い 場合に見られる低除水例である。

想定した小分子溶質は尿素様物質およびクレアチニ ン様物質で，これらの溶質の $K A$ および $\sigma$ に著者ら が報告した值息を用いた。これらを含め初期濃度, 初期 体液量などの入力パラメータを表 2 に一覧した。

\section{III. 結果および考察}

Pyle-Popovich のモデルで生成した仮想臨床デー 夕の各点において，3つの簡易式を適用して MTAC を求め, これを除水パターンごとに連続曲線として表
示した結果が図 2 (尿素様物質) および図 3 (クレアチ ニン様物質)である。図中スクリーンを施した部分は, $M T A C$ の正解(尿素では $20.0 \mathrm{ml} / \mathrm{min}$, クレアチニン では $13.0 \mathrm{ml} / \mathrm{min})$ に対して $5.0 \%$ の領域を表し，簡 易式の精度としてこの範囲で $M T A C$ が算出できるこ とを目標とした．これらの図は MTACをどの点(何分 目）で計算するかにより，值が異なることを意味する もので, MTAC が経時的に変化する様子を表したも のではない。

尿素様物質の場合 (図 2), Henderson の式や Babb -Garredの式を用いると，除水パターンごとに $M T A C$ が比較的高い精度で求められる時間帯が限ら れた範囲にあることがわかる。臨床では患者の腹膜除 水能を知る目的で PET 等の検査を行うのであり，予 め除水曲線に関する情報は得られない。これに対して 本簡易式を用いれば，除水能がどのような状態の患者 

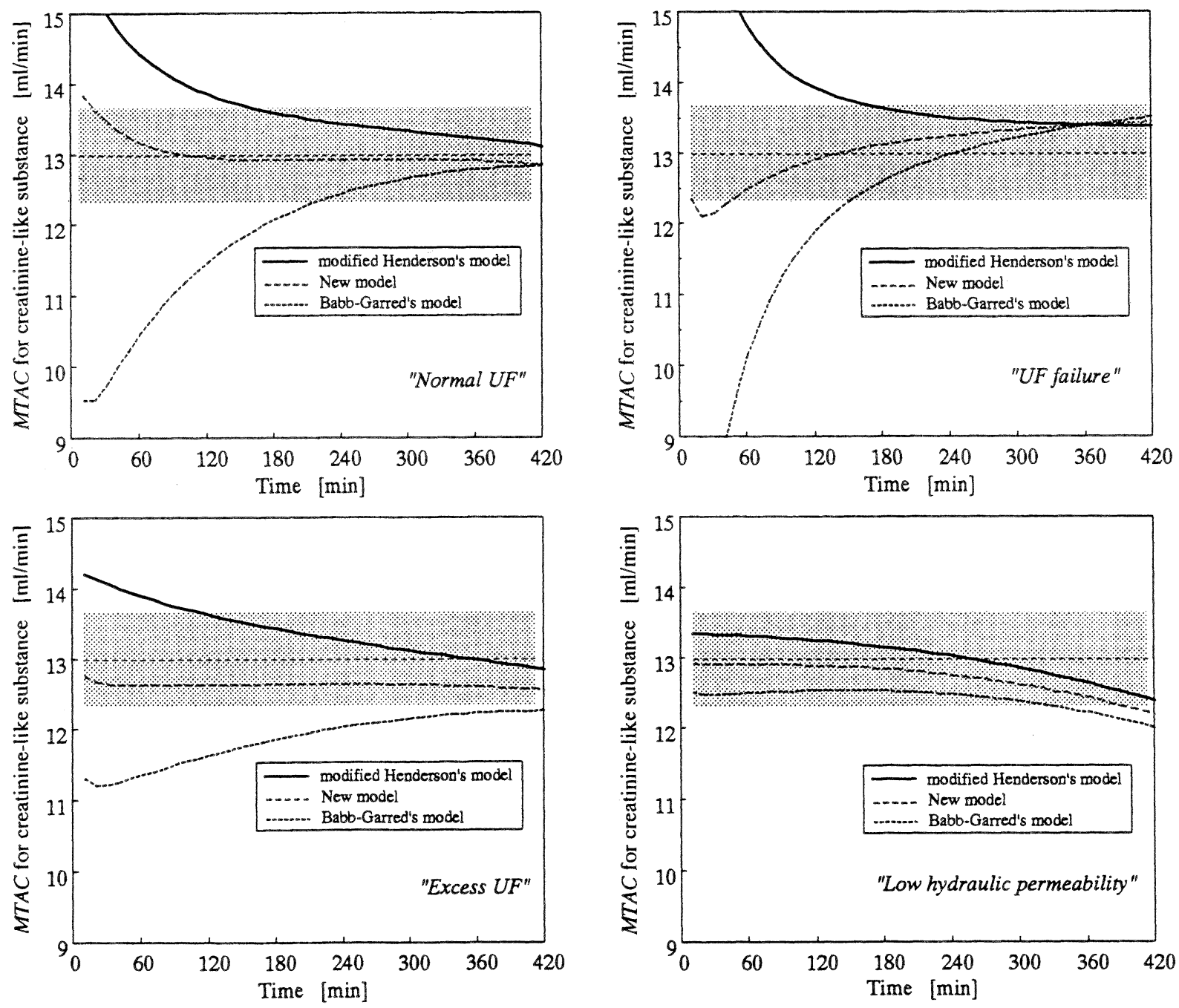

図 3 Comparison of three simple kinetic models in calculation of MTAC for creatinine-like substance Top-Left : "Normal UF" Bottom-Left : "Excess UF" Top-Right : "UF failure"

Bottom-Right: "Low hydraulic permeability"

でも，30〜240 分の任意の 1 点における $C_{D} / C_{B}(=D /$ $P$ 比)の值を用いて $\pm 5.0 \%$ 以内の誤差で $M T A C$ を求 められることがわかった。このことは $M T A C$ が小さ いクレアチニン様物質（図 3 ）において, より明らか であり，本簡易式を用いることにより，除水能の如何 によらず 400 分以内の任意の 1 点における $D / P$ 比の データから, $\pm 5.0 \%$ 以内の誤差で $M T A C$ を求めるこ とが可能である。

図 2，3 から Hendersonの式やBabb-Garredの式 を用いる場合には，何時間目にデー夕を採取するかが 重要な因子となることがわかる。これは本来定数であ るべき MATCが，PET のいわゆる“2 時間値”を用 いるか “4 時間值”を用いるかで，大きく影響を受ける ことを意味する，ところが本簡易式を用いれば，尿素 様物質，クレアチニン様物質のいずれの場合にも“2 時 間值”, “4 時間值”のどちらを用いても得られる
$M T A C$ の值にはほとんど変化がない.このことは, 2 時間ないしそれよりもさらに短い貯留時間で，正しい $M T A C$ が求められる可能性を示唆するものである. 3 つの MTAC の簡易算出式は

$$
\frac{C_{D}-\bar{C}_{B}}{C_{D}(0)-\bar{C}_{B}}=\left\{\frac{V_{D}(0)}{V_{D}}\right\}^{n} \exp \left(-\frac{K A}{\bar{V}_{D}} t\right)
$$

とまとめることができる。ここに，

$$
\mathrm{n}= \begin{cases}0 & \text { (Henderson の式) } \\ 1 & \text { (Babb-Garred の式) } \\ 1 / 2 & \text { (本簡易式) }\end{cases}
$$

である。さらに単一のデータのみ与えられている場合 （たとえば PETの 4 時間値）には，

$$
K A=-\frac{\bar{V}_{D}}{t} \ln \left[\left\{\frac{V_{D}}{V_{D}(0)}\right\}^{n} \frac{C_{D}-\bar{C}_{B}}{C_{D}(0)-\bar{C}_{B}}\right] \cdots
$$

と $K A$ について解いた形を用いれば，利用し易い。初 期濃度がほとんど無視できる場合には， 


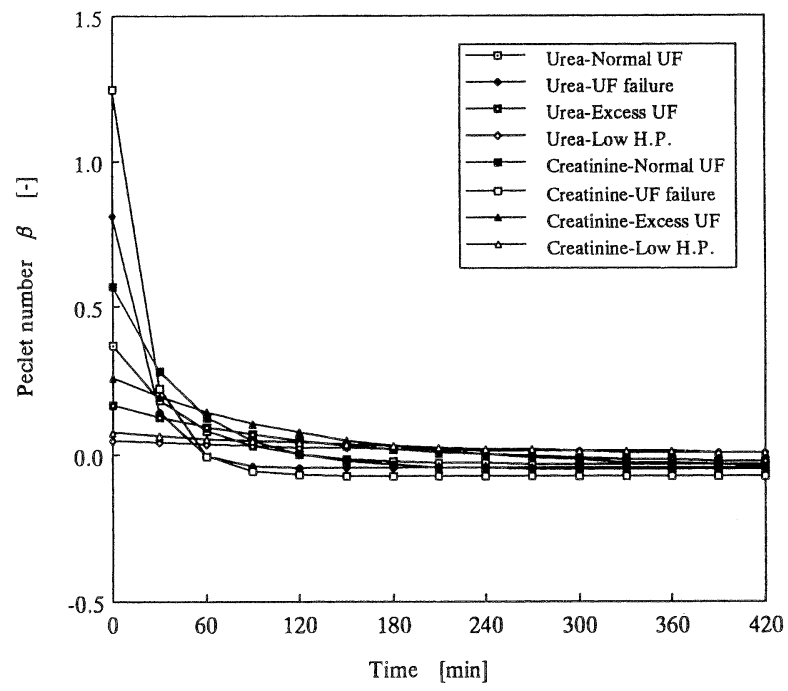

図 4 Time course of the Peclet number profile in various ultrafiltration patterns

$$
K A \approx-\frac{\bar{V}_{D}}{t} \ln \left[\left\{\frac{V_{D}}{V_{D}(0)}\right\}^{n}\left\{1-\left(\frac{D}{P}\right)_{t}\right\}\right]
$$

とさらに簡略化することもできる。ただし $(D / P)_{t}$ は 時刻 $t$ における血液中クレアチニン濃度に対する透析 液中クレアチニン濃度の比 $\left(=C_{D} / C_{B}\right)$ である.

これらの式の形は極めて良く似ているが，式を誘導 する際に用いる数学的な仮定は全く異なる. Hendersonの式では対流輸送が全く考慮されていないのに対 し, Babb-Garred の式では対流項に限外濾過流量と血 液側濃度の積が用いられているので，血液側から透析 液側への濾過が考慮されていることになる。ところが 実際には，血液側から透析液側への濾過は，透析液貯 留後のおよそ 2 時間に限られ，その後は逆に透析液側 から血液側へ正味の濾過が起こる。この現象を考慮す るためには, Pyle-Popovichのモデルまで遡って導出 した本簡易式を用いなければならない。これまで多く の臨床データの解析が, Henderson や Babb-Garred の式で行われてきた，小分子溶質の場合，透析液の全 貯留時間に渡って，通常は拡散輸送が対流輸送を遥か に上回る ${ }^{8)}$ た，Waniewski ら ${ }^{9)}$ が指摘するようにモ デル間には大きな差はなく，既報の解析結果に大きな 誤りはなかったものと考えられる。しかし 1〜3 時間程 度の短時間貯留データを用いた検討や，逆に除水過剰 例や低除水例を対照に 5 時間以上の貯留データをもと に, Henderson や Babb-Garredの式で MTACを算 出した場合，大きな誤差を招来する可能性がある.

これまでに採取されてきた膨大な PET による検査 データを，定量的な評価パラメータとして活用する場 合, MTAC の算出は不可欠である.しかし透析液貯留 中の溶質濃度や透析液量について，経時的な多点の

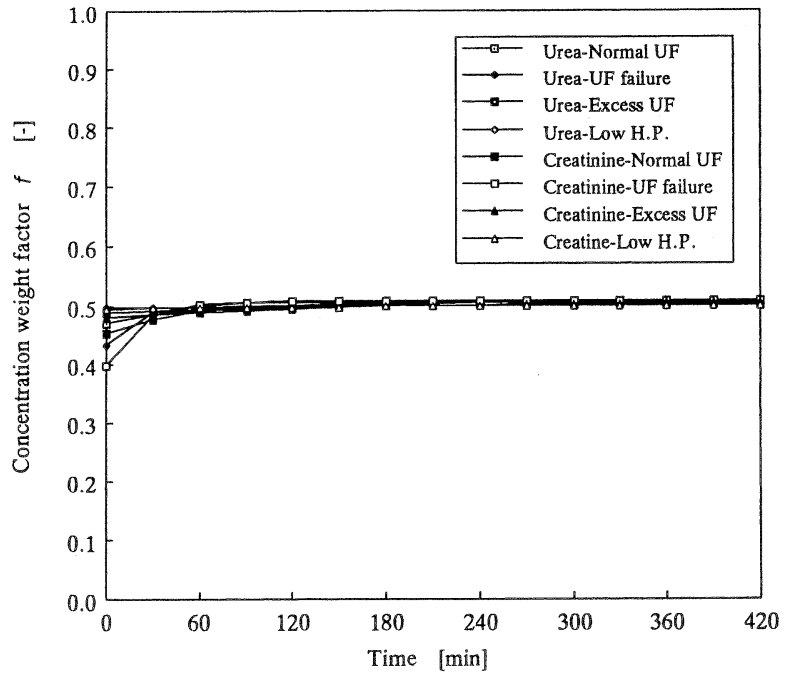

図 5 Time course of the concentration weight factor profile in various ultrafiltration patterns

デー夕採取は望めないので, Pyle-Popovich モデルの 適用は事実上難しい。これに対して，Hendersonや Babb-Garredの式は簡便ではあるが，算出された $M T A C$ が除水パターン（腹膜炎や除水不良症などの 病態)ごとに大きな誤差を生む可能性がある。したがっ てこれらを共通の算出式とした場合，長期に渡って値 の変化を評価することは難しい，本論文で提案した簡 易算出式は, 濾過に伴う物質移動に関して厳密性を 失っていない。そのため, 極端な除水条件を想定した 場合にも大きな誤差を生まず，実用性が高い指標であ ると思われた。

\section{結 論}

1) Pyle-Popovich モデルの論理性を損なうこと なく簡易化した実用的な $M T A C$ 算出式を導出した。

$2 ） こ の$ 簡易算出式は, Henderson や Babb-Garredの式よりも高い精度で MTAC を算出できること がわかった。

3 ）この簡易算出式を用いた MTAC の值は, 臨床 データの採取時間による影響を受けにくいので，短時 間での腹膜透過能の評価が可能である.

\section{摘 要}

第 1 項：濃度の重み因子 $f$ 値の決定

（4）式から明らかなように重み因子 $f$ は $\beta$ のみの関 数であるが, $\sigma=0.0$ と近似できる小分子溶質の場合 $\beta$ は (5) 式より $\beta=Q_{u} / K A$ となる。 $K A$ すなわち 
$M T A C$ は定数であるから， $\beta$ は $Q_{u}$ に比例する。本研 究では尿素とクレアチニンについて，4つの除水曲線 を想定したが，その合計 8 つ場合についてこの $\beta$ の 値をプロットすると，図4のようになる（図中のシン ボルは曲線を区別するためのものであり，実験值では ない)。この図からわかるように $\beta$ の值域は $-0.1<$ $\beta<1.3$ である。この $\beta$ に対して，(4)式を用いて $f$ を プロットすると図 5 が得られる。これから明らかなよ うに，初期において若干の変化が見られるが，60 分目 以降は総ての場合において $f \approx 0.5$ が成立しているこ とがわかる。この近似は小分子溶質のみにおいて成立 し，中大分子溶質に扔いては適用できない。また図 2, 3 で見られた本簡易式による MTAC の算出精度も， $f \approx 0.5$ の仮定の成立と重要な関係にある.

\section{第 2 項：(13) 式の導出}

（12）式を（1）式に代入し，

$$
\frac{d\left(V_{D} C_{D}\right)}{d t}=K A\left(\bar{C}_{B}-C_{D}\right)+Q_{u}\left(\frac{\bar{C}_{B}+C_{D}}{2}\right) \cdots \cdots(\mathrm{A})
$$

左辺の微分項を展開すると，

$$
\frac{d V_{D}}{d t} C_{D}+V_{D} \frac{d C_{D}}{d t}=K A\left(\bar{C}_{B}-C_{D}\right)+Q_{u}\left(\frac{\bar{C}_{B}+C_{D}}{2}\right)
$$

となる. 左辺第 1 項中の $d V_{D} / d t$ は，定義（または（7) 式)から明らかなように $Q_{u}$ に等しい.したがってこれ を右辺に移項して整理すると，

$$
\begin{aligned}
& V_{D} \frac{d C_{D}}{d t}=K A\left(\bar{C}_{B}-C_{D}\right)+Q_{u}\left(\frac{\bar{C}_{B}-C_{D}}{2}\right) \\
& V_{D} \frac{d C_{D}}{d t}=\left(K A+\frac{Q_{u}}{2}\right)\left(\bar{C}_{B}-C_{D}\right) \ldots \ldots \ldots . .
\end{aligned}
$$

となる。ここで変数を分離して，初期条件 $(t=0$ にお いて $\left.C_{D}=C_{D}(0)\right)$ に注意すると，

$$
\int_{C D(0)}^{C D} \frac{d C_{D}}{\bar{C}_{B}-C_{D}}=\int_{0}^{\mathrm{t}}\left(\frac{K A}{V_{D}}+\frac{1}{2} \frac{Q_{u}}{V_{D}}\right) d t
$$

という定積分が得られる。ここで右辺第 1 項の定積分 を行う際に，分母の $V_{D}$ の代わりにその平均值 $\bar{V}_{D}$ を用 いることにすると，他の積分は容易であるから，

$$
-\ln \left(\frac{\bar{C}_{B}-C_{D}}{\bar{C}_{B}-C_{D}(0)}\right)=\frac{K A}{\bar{V}_{D}} t+\frac{1}{2} \ln \left(\frac{V_{D}}{V_{D}(0)}\right)
$$

を得る，右辺第 2 項を左辺に移項して整理すると

$$
\ln \left[\left(\frac{V_{D}}{V_{D}(0)}\right)^{(1 / 2)} \frac{\bar{C}_{B}-C_{D}}{\bar{C}_{B}-C_{D}(0)}\right]=-\frac{K A}{\bar{V}_{D}} t
$$

となり,ここから最終的に,

$$
\frac{C_{D}-\bar{C}_{B}}{C_{D}(0)-\bar{C}_{B}}=\left\{\frac{V_{D}(0)}{V_{D}}\right\}^{(1 / 2)} \exp \left(-\frac{K A}{\bar{V}_{D}} t\right)
$$

が得られる。

第 3 項：(15）式の導出

$$
\begin{aligned}
\bar{V}_{D} & =\frac{\int_{0}^{t} V_{D} d t}{\int_{0}^{t} d t}=\frac{1}{t} \int_{0}^{t} V_{D} d t \\
& =\frac{1}{t} \int_{0}^{t}\left[V_{D}(0)+\frac{a_{1}}{a_{2}}\left\{\exp \left(a_{2} t\right)-1\right\}+a_{3} t\right] d t \\
& =\left(V_{D}(0)-\frac{a_{1}}{a_{2}}\right)+\frac{a_{3}}{2} t+\frac{a_{1}}{a_{2}{ }^{2} t}\left\{\exp \left(a_{2} t\right)-1\right\}
\end{aligned}
$$

\section{文献}

1）川西秀樹，熊谷純子，尾形 聡，小川貴彦，森石みさ き, 土谷晋一郎, 山中達彦, 土谷太郎：CAPD の長期 継続要因. 腹膜透析' 96, p 79-82, 東京医学社, 東京, 1996

2) Twadowski ZJ, Nolph KD, Khana R, Prowant BF, Ryan LP, Moore HL, Nielsen MP : Peritoneal equilibration test. Perit Dial Bull 7 : 138-147, 1987

3) Popovich RP, Pyle WK, Bomar JB, Moncrief JW : Peritoneal dialysis. Chronic replacement of kidney function. Amer Inst Chem Eng Symp Series 187, $75: 31-45,1979$

4) Henderson LW : Altered permeability of the peritoneal membrane after using hypertonic peritoneal dialysis fluid. J Clin Invest 48 : 992-1001, 1969

5) Babb AL, Johansen PJ, Strand MJ, Tenckhoff $H$, Scribner $\mathrm{BH}$ : Bi-directional permeability of the human peritoneum to middle molecules. Proc Eur Dial Transplant Assoc $10: 247-262,1973$

6) Garred LJ, Canand B, Farrell PC : A simple kinetic model for assessing peritoneal dialysis. ASAIOJ 6 : 131-137, 1983

7) 熊野和雄, 酒井 紏, 山下明泰: Automated Peritoneal Dialysis における至適透析条件の検討. 人工藏 器 $21: 893-897,1992$

8）山下明泰, 南雲裕子, 日台英雄, 熊野和雄, 飯高喜久 雄, 酒井 紏：CAPD における分子拡散項と対流項の 溶質輸送効果。人工藏器 $14: 111-114,1985$

9) Waniewski J, Werynski A, Heimburger O, Lindholm B : A comparative analysis of mass transfer models in peritoneal dialysis. Trans ASAIO $37: 65$ $-75,1991$ 